\title{
ANALYSIS OF THE WORLDWIDE CONCENTRATION OF PELLET IMPORTS (2012-2018)
}

\author{
Helena Cristina Carvalho Soares ${ }^{2} \odot$, Álvaro Nogueira de Souza ${ }^{3} \odot$, Edvaldo Pereira Santos Júnior ${ }^{4} \odot$,
}

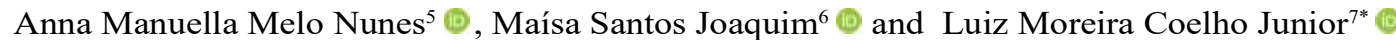

\footnotetext{
${ }^{1}$ Received on 26.05.2021 accepted for publication on 03.09.2021.

${ }^{2}$ Universidade de Brasília, Programa de Pós-Graduação em Ciências Florestais, Brasília, DF- Brasil. E-mail: < helenacclodi@gmail.com>.

${ }^{3}$ Universidade de Brasília, Departamento de Engenharia Florestal, Brasília, DF- Brasil. E-mail: <ansouza@unb.br>.

${ }^{4}$ Universidade Federal de Pernambuco, Programa de Pós-Graduação em Tecnologias Energéticas e Nucleares, Recife, PE - Brasil. E-mail: <edvaldo.junior@ufpe.br>.

${ }^{5}$ Universidade Federal da Paraíba, Programa de Pós-Graduação em Engenharia de Energias Renováveis, João Pessoa, PB - Brasil. E-mail: <annamanuellam@gmail.com>.

${ }^{6}$ Universidade de Brasília, Departamento de Gestão de Agronegócio, Brasília, DF- Brasil. E-mail: <maisajoaquim@unb.br>.

${ }^{7}$ Universidade Federal da Paraíba, Departamento de Engenharia de Energias Renováveis, João Pessoa, PB - Brasil. E-mail: <luiz@cear. ufpb.br>.

*Corresponding author.
}

\begin{abstract}
Faced with the transition in the global energy structure with the shift in consumption of fossil fuels to renewable and clean sources, there has been an increase in the demand for forest biomass for energy purposes, especially wood pellets, and imports have grown in recent years. Therefore, this study analyzed the world concentration of pellet imports from 2012 to 2018. Data on pellet imports were obtained from the Food and Agriculture Organization of the United Nations (FAO), and the following indicators were used to measure the concentration: Concentration Ratio [CR(k)], Hirschman-Herfindal Index (HHI), Theil Entropy Index (E), Gini Inequality Coefficient (G) and the Hall-Tideman Index (HTI). The results showed a growth of 16.67\% p.a. of global pellet imports, from 8.76 million tons (t) in 2012 to 22.15 million tons in 2018 . The CR(k) indicated very high concentration for countries and high in the subcontinents. The HHI showed a high concentration for continents and subcontinents and a moderate concentration for countries. Entropy and HTI corroborated the analyzes found in the HHI. The G pointed out strong inequality for all territorial levels and showed trends towards a reduction in inequality as of 2015. The reduction in the concentration in the final years of study is related to the expansion and technological diffusion of energy conversion of the densified biomass, which makes this fuel more affordable.
\end{abstract}

Keywords: Bioenergy; Densified biomass; Forest economy.

\section{ANALLISE DA CONCENTRAÇÃO MUNDIAL DAS IMPORTAÇÕES DE PELLETS (2012-2018)}

\begin{abstract}
RESUMO - Diante da transição na estrutura energética mundial, com o deslocamento do consumo dos combustiveis fósseis para fonte renováveis e limpas, registra-se um aumento da demanda por biomassa florestal para fins energéticos, em especial os pellets de madeira, e as importações têm crescido nos últimos anos. Logo, este artigo analisou a concentração mundial das importações de pellets, de 2012 a 2018. Os dados de importações de pellets foram obtidos da Food and Agriculture Organization of the United Nations - FAO e para mensurar a concentração foram utilizados os indicadores: Razão de Concentração [CR(k)], Índice de Hirschman-Herfindal (HHI) Índice de Entropia de Theil (E), Coeficiente de desigualdade de Gini (G) e o Índice de Hall-Tideman (HTI). Os resultados apontaram um crescimento de 16,67\% a.a. da importação mundial de pellets, saindo de 8,76 milhões toneladas ( $t$ ), em 2012, para 22,15 milhões de tem 2018. Quanto aos indices de concentração, o $C R(k)$ indicou concentração muito alta para os países e alta nos subcontinentes. $O H H I$ apresentou concentração alta para os continentes e subcontinentes e uma concentração moderada para os países. A Entropia e o HTI corroboraram as análises encontradas no HHI. O G apontou forte desigualdade
\end{abstract}

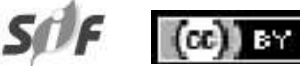

Revista Árvore 2021;45:e4540 http://dx.doi.org/10.1590/1806-908820210000040 


\begin{abstract}
para todos os níveis territoriais e apresentou tendências de redução na desigualdade a partir de 2015. A redução da concentração, nos últimos anos de estudo, encontra relação com a expansão e a difusão tecnológica de conversão energética da biomassa densificada, o que torna o combustível mais acessível.
\end{abstract}

Palavras-Chave: Bioenergia; biomassa densificada; economia florestal.

\section{INTRODUCTION}

There has been a change in the global energy structure and an increase in the demand for energy from renewable sources to replace oil and its derivatives in recent decades (Nunes et al., 2016). The United Nations (UN, 2012) outlined actions so that countries around the world would have access (in terms of prices and quality) to sustainable energy by 2030. In response to the concern about climate change and its effects, 195 countries signed an agreement in 2015 through the Paris Climate Change Conference (COP21), which encouraged the transition to lowcarbon, cleaner, renewable and sustainable energy (Johannsdottir and Mcinerney, 2016).

Biomass will provide $7.5 \%$ of energy generation by 2050 on a global scale, reducing 1.3 billion tons of $\mathrm{CO}_{2}$ equivalent emissions per year. Thus, densified biofuels, such as pellets, become an alternative in the world energy market, making it feasible to meet the targets for reducing greenhouse gas (GHG) emissions. The use of pellets has an impact of six times less than fuel oil per $\mathrm{kWh}$ generated in residential use (Caraschi and Garcia, 2012; Kovalyshyn, 2019; Pinel, 2013).

The electricity sector is one of the main spheres of the economy subject to GHG emission reduction targets. Thermoelectric plants are the biggest demander of fuel pellets in Europe, which imported 17.3 million tons ( $\mathrm{t}$ ) of wood pellets, representing $78.23 \%$ of world imports in 2018. The population needs thermal comfort and energy replacement (fossil fuels) with less polluting sources, subsidizing the purchase of heaters and thermoelectric pellets. The growth in imports of wood pellets boosts the dynamics of the international market, bringing effects on the market structure, prices, investments and production in countries (Aghion et al, 2005; Arranz et al., 2015; FAO, 2020; Tavares and Tavares, 2015; Trømborg et al., 2013).

Concentration is an important element in industrial organization to determine market structure behavior, since it is inversely proportional to competitiveness (Resende, 1994). The term concentration can be understood as an accumulation of economic attributes by corresponding control units (Braga and Mascolo, 1982). Market concentration becomes a determinant of competitiveness, as it affects the economy of scale, size and strategies of firms (Resende, 1994; Kon, 1999; Noce et al., 2007). Market concentration can be statically analyzed in a time frame, and/or dynamically based on a time series (Kon, 1999).

Some market concentration tests in the forestry sector were developed in the international scenario in the $21^{\text {st }}$ century by Coelho Junior et al. (2013) for forest products, Noce et al. (2007) for plywood, Coelho Junior et al. (2010) and Coelho Junior et al. (2018) for cellulose; Selvatti et al. (2018) and Coelho Junior (2019a) for Medium Density Fiberboard (MDF); and for Brazil with Simioni et al. (2017) and Coelho Junior et al. (2019b; 2019c) for firewood and charcoal, and Coelho Junior et al. (2020; 2021) for forest-based thermoelectric plants. In order to understand the market structure of wood pellet imports, this article evaluated the concentration of the wood pellet import market in the period from 2012 to 2018 based on concentration and inequality measures.

\section{MATERIAL AND METHODS}

\subsection{Data used}

The data used to measure the concentration of pellet imports were obtained from the FAO from 2012 to 2018 . The indicators identify the degree of concentration and make it possible to understand its evolution over time (Noce et al., 2007). A regional cut was used to analyze the pellet import situation: the continents, the ten largest importing countries, based on 2018, and Brazil. The Geometric Growth Rate (GGR) (Equation 1) was used to estimate and assess gains and losses from pellet imports in the international market (Cuenca and Dompieri, 2016).

Revista Árvore 2021;45:e4540 


$$
G G R=\left[\left(n \sqrt{\frac{V_{n}}{V_{0}}}\right)-1\right] * 100
$$

In which: $V_{n}$ is the relative value of pellet imports in the final year; $V_{0}$ is the value referring to pellet imports in the initial year; $n=$ temporal variation (expressed in years).

\subsection{Concentration and inequality measures}

Table 1 shows the concentration and inequalities indicators used in this study: the Concentration Ratio $[\mathrm{CR}(\mathrm{k})]$; the Hirschman-Herfindal Index (HHI); the Theil Entropy Index (E); the Gini Inequality Coefficient (G), and the Hall-Tideman Index (HTI).

The Concentration Ratio [CR(k)] (Equation 2) is the sum of the $\mathrm{k}$ (where $\mathrm{k}=1,2, \ldots, \mathrm{n}$ ) shares of regions, firms, goods and services in the market (Bain, 1959). It was used to calculate the concentration ratio of the four [CR(4)] and eight [CR(8)] largest (countries and subcontinents) pellet importers and were classified according to Bain (1959). It also looked at imports from the top 20 [CR(20)] and 30 [CR(30)] countries and the two largest $[\mathrm{CR}(2)]$ subcontinents.

The Herfindahl-Hirschman Index (HHI) (Equation 3) uses the sum of the squared participation of $i$ participants (countries, subcontinents and continents), showing the relative weights of importers. The HHI varies between $1 / \mathrm{n}$ (where all regions import the same amount) and 1 (maximum concentration, monopoly). When there is a variation of importers over time, the lower limit $(1 / \mathrm{n})$ also varies, making intertemporal comparison difficult. Thus, Resende (1994) proposed the adjusted Herfindahl-Hirschman Index (HHI') to solve this limitation (Equation 4), for which the limits of the HHI' are between 0 and 1 and classified according to Coelho Junior et al. (2018).

Resende and Boff (2002) indicated the use of Theil's Entropy Index (E) (Equation 5) as it measures the inverse of the HHI, meaning that the smaller the $\mathrm{E}$, the more concentrated the market. Analogously to the HHI, Resende (1994) suggested the adjusted Theil Entropy Index (E') (Equation 6) for intertemporal analyses. The E' varies between 0 (monopoly) and 1 (perfect competition).

The Gini Coefficient Index (G) (Equation 7) was initially developed to measure population income inequality (Gini, 1912). However, it can be used to measure the degree of inequality existing in pellet imports in the world, since the higher the concentration, the higher the inequality. The $\mathrm{G}$ ranges between 0 and 1 , and used the classification by Coelho Junior et al. (2013). The Hall-Tideman Index (HTI) is an inequality indicator that considers all pellet importers involved in the activity, incorporating the ranking number to the participation of each one (Equation 8 ). The HTI varies between $1 / \mathrm{n}$ (condition of perfect equality) and 1 (condition of monopoly or absolute inequality).

\section{RESULTS}

Figure 1 shows the evolution of the continents in pellet imports, in millions of tons $\left(\times 10^{6} \mathrm{t}\right)$, from 2012

Table 1 - Concentration and inequality measures.

Tabela 1 - Medidas de concentração e desigualdade.

\begin{tabular}{|c|c|c|c|}
\hline Indices & Equation & Interval & \\
\hline Concentration ratio & $C R(k)=\sum_{i=1}^{k} S_{i}$ & $0 \leq \mathrm{CR}(\mathrm{k}) \leq 1$ & Eq. 2 \\
\hline Herfindahl-Hirschman & $H H I=\sum_{i=1}^{n} S_{i}^{2}$ & $1 / n \leq H H I \leq 1$ & Eq. 3 \\
\hline Adjusted Herfindahl-Hirschman Index & $H H I^{\prime}=\frac{1}{n-1}\left(n^{*} H H I-1\right) ; n>1$ & $0 \leq H H I \leq 1$ & Eq. 4 \\
\hline Theil Entropy Index & $E=-\sum_{i=1}^{n} S_{i} \ln \left(S_{i}\right)$ & $0 \leq E \leq \ln \left(\mathrm{S}_{\mathrm{i}}\right)$ & Eq. 5 \\
\hline Adjusted Theil Entropy Index & $E^{\prime}=-\frac{1}{\ln n} \sum_{i=1}^{n} S_{i} \ln \left(S_{i}\right)$ & $0 \leq E^{\prime} \leq 1$ & Eq. 6 \\
\hline Gini Coefficient Index & $\left.G_{G=1}\left[\sum_{i=1}^{n}\left(S_{s}+S_{i}\right)\right]\right]^{i=1}$ & $0<G \leq 1$ & Eq. 7 \\
\hline Hall-Tideman Index & $H T I=\frac{n^{n}}{2 \sum_{i=1}^{n}\left(i S_{i}\right)-1}$ & $0 \leq \mathrm{HTI} \leq 1$ & Eq. 8 \\
\hline
\end{tabular}

In which: $\mathrm{n}=$ number of participants, $\mathrm{S}_{\mathrm{i}}=$ market share, in percentage, of region $\mathrm{i}$ (country, subcontinent and continent) in the world pellet import, $\ln =$ neperian logarithm, $\mathrm{S}_{\mathrm{i}}=$ market Accumulated share, in percentage, of region i (country, subcontinent and continent) in the world pellet import.

Source: Bain (1959); Coelho Junior et al. (2018); Resende and Boff (2002); Gini (1912).

Em que, $\mathrm{n}=$ número de participantes, $\mathrm{S}_{\mathrm{i}}=$ market share, em porcentagem, da região $\mathrm{i}$ (país, subcontinente e continente) na importação mundial de pellets, ln $=$ logaritmo neperiano, $\mathrm{S}_{\mathrm{ij}}=$ market share, em porcentagem, acumulado, da região $\mathrm{i}$ (país, subcontinente e continente) na importação mundial de pellets.

Fonte: Bain (1959); Coelho Junior et al. (2018); Resende e Boff (2002); Gini (1912). 


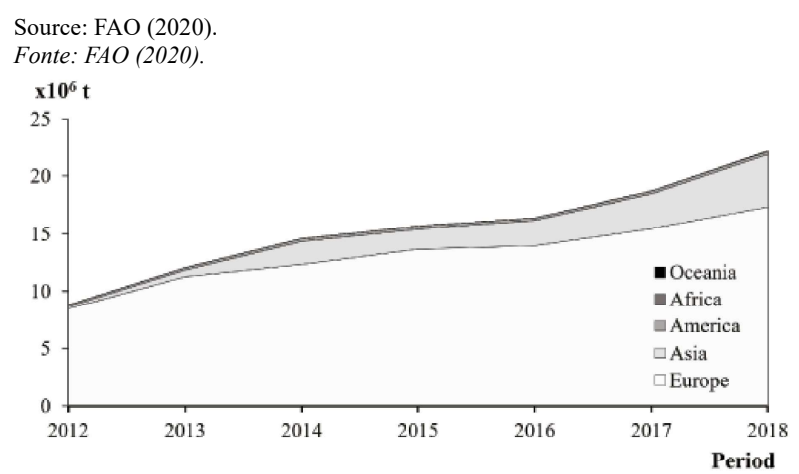

Figure 1 - Evolution of the continents in pellet imports in millions of tons ( $\times 10^{6} \mathrm{t}$ ) from 2012 to 2018 .

Figura 1 - Evolução dos continentes nas importações de pellets, em milhões de toneladas (x106 t), de 2012 a 2018.

to 2018. Table 2 shows the evolution of the ten largest and Brazil based on 2018, and the ranking of the ten largest and Brazil in pellet imports in thousand tons $\left(\mathrm{x} 10^{3} \mathrm{t}\right)$ from 2012 to 2018.
Figure 2 shows the evolution of the Concentration Ratio $[\mathrm{CR}(\mathrm{k})]$ of pellet imports in the world, Figure 2 shows countries of the subcontinents (Figure 2B) from 2012 to 2018. Figure 3 shows the evolution of the concentration and inequality indicators of pellet imports in the world from 2012 to 2018, the Herfindahl-Hirschman Index (HHI) of countries (Figure 3A), subcontinents (Figure 3B), continents (Figure 3C) and the adjusted HHI (HHI') (Figure 3D); Theil Entropy Index (E) of countries (Figure 3E), subcontinents (Figure 3F), continents (Figure 3G), and the adjusted E (E') (Figure 3H), Gini Coefficient Index (G) (Figure 3I), and the Hall-Tideman Index (HTI) (Figure 3J).

\section{DISCUSSION}

As shown in Figure 1, world imports of wood pellets started at 8.78 million $t$ in 2012 and reached 22.15 million $t$ in 2018 , showing an annual increase of

Table 2 - Evolution of the ten pellet importing countries and Brazil, based on 2018, and the import ranking of the ten countries and Brazil in thousand tons $\left(\mathrm{x} 10^{3} \mathrm{t}\right)$ from 2012 to 2018.

Tabela 2 - Evolução dos dez países importadores de pellets e o Brasil, com base em 2018, e o ranking da importação dos dez países e do Brasil, em mil toneladas $\left(x 10^{3} \mathrm{t}\right)$, de 2012 a 2018.

\begin{tabular}{|c|c|c|c|c|c|c|c|c|}
\hline & 2012 & 2013 & 2014 & 2015 & 2016 & 2017 & 2018 & GGR (\%) \\
\hline United Kingdom & $1,486.88$ & 3389 & $4,757.14$ & $6,573.19$ & $6,781.61$ & $6,885.24$ & $7,046.96$ & 29.6 \\
\hline Denmark & 2016 & 2236 & 2256.1 & 2072 & 2053 & 2818 & 3813 & 11.21 \\
\hline South Korea & 122.45 & 484.67 & $1,849.64$ & $1,470.68$ & $1,716.64$ & $2,431.17$ & $3,445.14$ & 74.4 \\
\hline Italy & 1197 & $1,748.73$ & $1,935.96$ & $1,653.6$ & $1,663.82$ & $1,792.55$ & 2,242 & 11.03 \\
\hline Belgium & 970.47 & 896.19 & 657.76 & 985.62 & 906.48 & $1,090.92$ & $1,137.3$ & 2.68 \\
\hline Japan & 71.98 & 83.77 & 96.75 & 232.43 & 346.86 & 506.35 & $1,059.54$ & 56.55 \\
\hline Germany & 347.47 & 546.62 & 419.38 & 445.79 & 443.1 & 431.59 & 390.24 & 1.95 \\
\hline Sweden & 493.04 & 712.65 & 521.63 & 354.94 & 267.98 & 272.26 & 379.96 & -4.25 \\
\hline Austria & 272.14 & 385.46 & 343.85 & 367.84 & 392.2 & 403.47 & 360.04 & 4.78 \\
\hline France & 25.63 & 92.02 & 170.63 & 157.26 & 248.86 & 270.77 & 274.77 & 48.49 \\
\hline$\overline{\text { Brazil }}$ & 0.31 & 1.16 & 0.45 & 0.37 & 0.82 & 0.87 & 1.28 & 27.05 \\
\hline Rest of the world & $1,779.96$ & $1,479.22$ & $1,578.79$ & 1,351 & $1,565.1$ & $1,797.63$ & $2,001.2$ & 1.97 \\
\hline World & $8,785.33$ & $12,057.5$ & $14,590.08$ & $15,666.73$ & $16,388.48$ & $18,702.83$ & $22,153.45$ & 16.67 \\
\hline$\overline{1 s t}$ & DNK & GBR & GBR & GBR & GBR & GBR & GBR & \\
\hline 2nd & GBR & DNK & DNK & DNK & DNK & DNK & DNK & - \\
\hline 3rd & ITA & ITA & ITA & ITA & ROK & ROK & ROK & \\
\hline 4th & NLD & BEL & $\mathrm{ROK}$ & $\mathrm{ROK}$ & ITA & ITA & ITA & - \\
\hline 5th & BEL & SWE & BEL & BEL & BEL & BEL & BEL & - \\
\hline 6th & SWE & DEU & SWE & DEU & DEU & JPN & JPN & - \\
\hline 7th & DEU & NLD & NLD & AUT & AUT & DEU & DEU & - \\
\hline 8th & AUT & ROK & DEU & SWE & JPN & AUT & SWE & - \\
\hline 9th & POL & AUT & AUT & JPN & SWE & SWE & AUT & - \\
\hline 10th & ROK & USA & USA & USA & FRA & FRA & FRA & - \\
\hline Brazil & $44^{\circ}$ & $41^{\circ}$ & $51^{\circ}$ & $52^{\circ}$ & $49^{\circ}$ & $55^{\circ}$ & $52^{\circ}$ & - \\
\hline No. of countries & 76 & 85 & 85 & 92 & 89 & 91 & 90 & - \\
\hline
\end{tabular}

Revista Árvore 2021;45:e4540 
$16.67 \%$ pa. Europe was the main continent responsible for more than $3 / 4$ of the operations with a share of $96.17 \%$, followed by Asia $2.33 \%$ and America $1.5 \%$. The purchase of wood pellets by Africa and Oceania was not significant. Europe accounted for $78.24 \%$ of the 22.15 million tons imported in 2018, Asia for $20.57 \%$, America for $1.12 \%$, Africa for $0.69 \%$ and Oceania for $0.006 \%$. According to FAO (2020), the world import of this biomass reached the amount of 3.7 billion dollars in 2018. The African continent had low participation, but it grew the most in relative annual terms (90.21\% p.a.), going from $322 \mathrm{t}$ (2012) to 15.25 thousand $\mathrm{t}$ (2018). Bowd et al. (2018) highlighted that the main wood pellet firms in the Southern Africa region (Southern Africa) closed their production activities by 2013 , either for logistical or technological reasons, providing an increase of $93.97 \%$ p.a. pellet imports in this sub-region.

Asia jumped from $204.71,000 \mathrm{t}$ in 2012 to 4.55 million $t$ in 2018 , with an average growth of $67.72 \%$ p.a., caused by the increase in demand for electricity in Asian countries due to the Belt Initiative and Belt and Road Initiative (BRI). This movement intensified China's trade and investment in BRI member countries, mainly in renewable energies (Le and Vo, 2020). The other continents presented growth of $29.50 \%$ p.a. in Oceania, $12.72 \%$ p.a. in Europe and $11.11 \%$ p.a. in America.

It was observed in Table 2 that the ten main pellet importers in the world in 2018 were: United
Kingdom, Denmark, South Korea, Italy, Belgium, Japan, Germany, Sweden, Austria and France. The top 10 pellet importing countries had a growth rate of $19.26 \%$ per year, well above the world average $(16.67 \%)$ per year. Among them, South Korea had the highest average annual increase $(74.39 \%$ p.a.), while Sweden was the smallest ( $-4.25 \%$ p.a.). According to Proskurina et al. (2019), the increase in the use of wood pellets in South Korea was due to the process of replacing coal in thermoelectric plants. Eastern European countries and the United States are next after the 10 biggest importing countries.

The Netherlands and Poland left the top 10 list by 2018, which in turn were replaced by Japan and France, and the other countries only alternated positions among themselves. France also increased its imports more than ten times for the same period with a growth of $48.49 \%$ p.a., a reflection of investments and incentives from the French government to increase renewable energy consumption. The Programme d'investissements d'avenir (PIA2) launched by the French government in July 2013, made an investment of $€ 6$ million (US\$7.8 million) towards the development of renewable energy sources (MER, 2014). The French government also reduced the Value Added Tax (VAT) (the tax equivalent to ICMS in Brazil) from $19 \%$ to $5.5 \%$ for the purchase of products related to the consumption of pellets, such as residential and commercial heaters (European Biomass Association - AEBIOM, 2021).
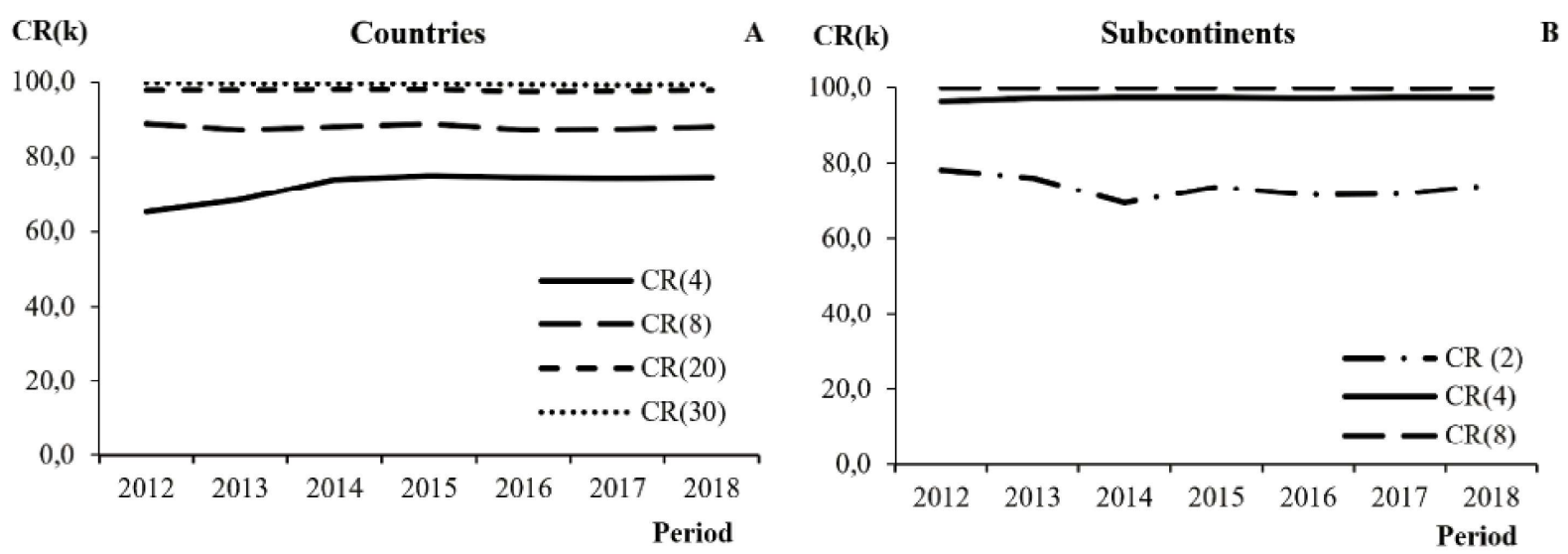

Figure 2 - Evolution of the Concentration Ratio [CR(k)] of pellet imports in the world through countries (A) and subcontinents (B) from 2012 to 2018

Figura 2 - Evolução da Razão de Concentração [CR(k)] das importações de pellets no mundo, por meio dos países (A) e dos subcontinentes (B), de 2012 a 2018. 

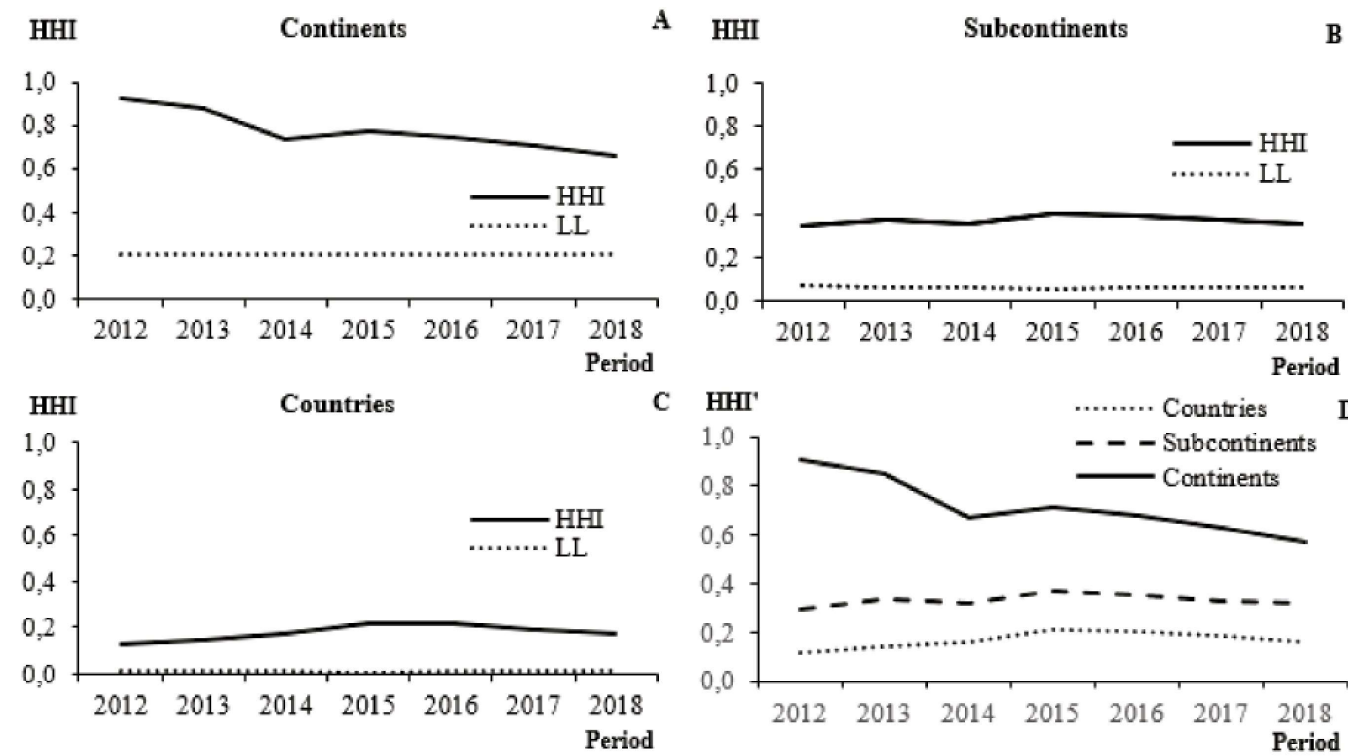

C $\mathrm{HHI}^{\prime}$
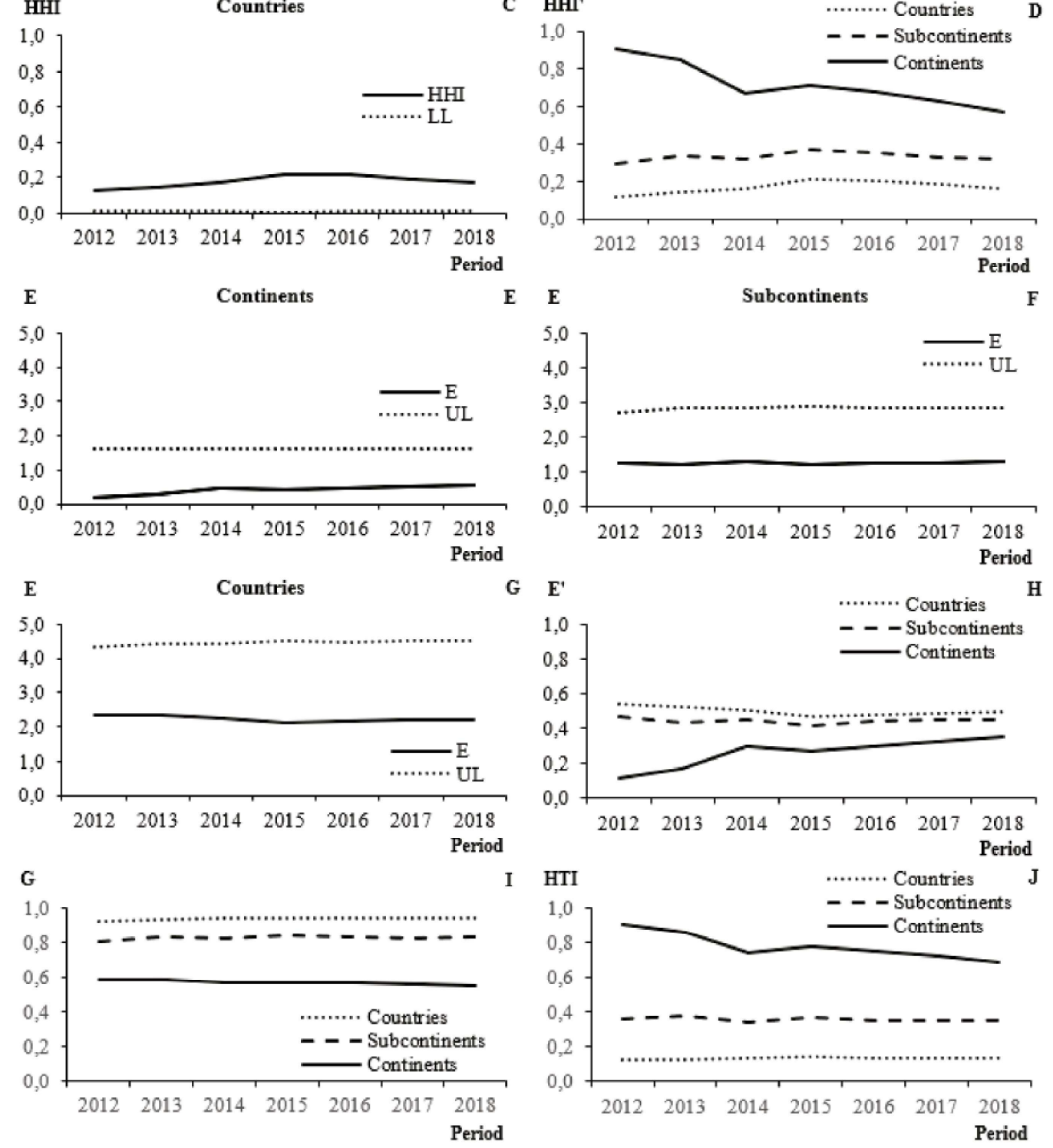

Figure 3 - Evolution of (a, b, c, d) the Herfindahl-Hirschman Index (HHI), (e, f, g, h) Theil Entropy (E), (i) Gini Coefficient Index (G) and (j) the Hall-Tideman Index (HTI) for the worldwide import of pellets from 2012 to 2018.

Figura 3 - Evolução do ( $a, b, c, d)$ Índice de Herfindahl-Hirschman (HHI), (e, $f, g, h)$ Entropia de Theil (E), (i) Coeficiente de Gini (G) e (j) Índice de Hall-Tideman (HTI) para a importação mundial de pellets, de 2012 a 2018.

\section{Revista Árvore 2021;45:e4540}


Japan was the second country with the highest average annual growth in pellet imports $(56.55 \%$ p.a.), going from 71.98 thousand $t$ in 2012 to 1.06 million $\mathrm{t}$ in 2018 , increasing imports by almost fifteen times. This increase was similar to the French and South Korean growth due to energy planning for 2030, aiming to meet the commitments signed with the Paris Agreement. It determined the electricity produced to be between $22 \%$ and $24 \%$ renewable energy to achieve the goals for reducing the emission of greenhouse gases. Japan has become one of the main pellet players in the world and is estimated to import between 10 and 20 million tons of pellets from Brazil by 2030 (Mapa, 2016).

Brazil occupied the $44^{\text {th }}$ position (importing 301 t) in the world ranking of pellet importers in 2012, and moved to $52^{\text {nd }}$ in 2018 with more than 128,000 t. The consumption of pellets in Brazil is still low and is concentrated in supplying heat, mainly in pizzerias, gyms, hotels, homes and small and medium-sized industries (Caraschi and Garcia, 2012). In addition to the countries included in Table 2, countries like Macedonia (214.97\% p.a.), South Africa (103.35\% p.a.) and Romania (76.73\% p.a.) stand out.

The concentration ratio of countries $\left[\mathrm{CR}(\mathrm{k})_{\mathrm{c}}\right]$ showed a very high concentration, with an increase in $\mathrm{CR}(4)_{\mathrm{c}}$ and stability in the other levels studied $[\mathrm{CR}(8)$ c, $\mathrm{CR}(20)_{\mathrm{c}}$ and $\left.\mathrm{CR}(30)_{\mathrm{c}}\right]$. The $\mathrm{CR}(4)_{\mathrm{c}}$ went from $65.25 \%$ (2012) to $75.12 \%$ (2015), and then decreased to $74.69 \%$ (2018). The average for the period was $72.38 \%$, which characterized the market as having a high concentration (Bain, 1959) and a standard deviation of 3.86 , indicating little change in relation to the average. The six main importing countries were: Denmark, United Kingdom, Italy, the Netherlands, Belgium and South Korea. According to Scherer and Ross (1990), the structure is oligopolistic when CR(4) c hold more than $40 \%$ of the market.

The concentration ratio of the 8 largest countries $\left[\mathrm{CR}(8)_{\mathrm{c}}\right]$ had maximum values of $88.96 \%$ (2012), a minimum of $87.20 \%$ (2013) and an average of $87.99 \%$, characterizing a high market concentration. The participation in $\mathrm{CR}(8)_{\mathrm{c}}$ alternated: Austria, Belgium, Denmark, Germany, Italy, Japan, Netherlands, South Korea, Sweden and the United Kingdom. The concentration ratio of $20\left[\mathrm{CR}(20)_{\mathrm{c}}\right]$ and $30[\mathrm{CR}(30)$ c] reached close to $100 \%$ of the market and showed that the addition of the $21^{\text {st }}$ to the $30^{\text {th }}$ countries added an average of $1 \%$ of the market, meaning that the 20 largest countries dominate pellet imports.

There was participation from 15 (2012) to 18 (2015) in the subcontinents, and 17 subcontinents in 2018. The concentration ratio of the 2 largest subcontinents $\left[\mathrm{CR}(2)_{\mathrm{s}}\right]$ was between $78.13 \%$ (2012) and $69.40 \%$ (2014), and the regions which composed them were: Northern Europe and Western Europe (2012, 2013, 2015 and 2016), Northern Europe and Southern Europe (2014), and Northern Europe and East Asia (2017 and 2018), driven by South Korean and Japanese growth.

The concentration ratio of the 4 largest subcontinents [CR(4) ] evolved from $96.16 \%$ (2012) to $97.23 \%$ (2018) and an average of $97.02 \%$, indicating a very high concentration and the main importers were: North from Europe, Eastern Europe, Southern Europe, Western Europe and East Asia. The concentration ratio of the 8 largest subcontinents $\left[\mathrm{CR}(8)_{\mathrm{s}}\right]$ was $99.97 \%$ (2012) to $99.91 \%$ (2018), with an average of $99.94 \%$ and classified as very high concentration. Costa et al. (2018) analyzed the concentration of Brazilian exports of chemical cellulose and verified the drop in concentration due to the increased share of importing countries of Brazilian chemical cellulose. But this behavior was not observed in pellet imports in the studied $\mathrm{CR}(\mathrm{k})$ indicators.

The HHI was observed at the continental $\left(\mathrm{HHI}_{\text {con }}\right)$, subcontinental $\left(\mathrm{HHI}_{\mathrm{s}}\right)$ and country $\left(\mathrm{HHI}_{\mathrm{c}}\right)$ levels. There was an approximation to the Lower

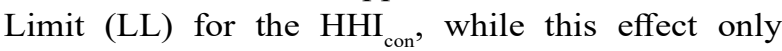
occurred from 2015 onwards for the $\mathrm{HHI}_{\mathrm{s}}$ and $\mathrm{HHI}_{\mathrm{c}}$. The approximation of the HHI' to the LL', indicates a drop in concentration, as pointed out by the $\mathrm{CR}(\mathrm{k})$ and $\mathrm{CR}(\mathrm{k})_{\mathrm{s}}$. Since the LL depends on the number of participants, the LL of the continents $\left(\mathrm{LL}_{\mathrm{con}}\right)$ was constant, while the LL of the subcontinents $\left(\mathrm{LL}_{\mathrm{s}}\right)$ and the LL of the countries ( $\mathrm{LL}_{\mathrm{c}}$ ) had some annual variation. The mean of the HHIcon was 0.7749 and the $\mathrm{LL}_{\text {con }}$ of 0.20 , with a mean difference of 0.5749 . The average difference between $\mathrm{HHI}_{\mathrm{s}}$ and $\mathrm{LL}_{\mathrm{s}}$ for the subcontinents was 0.3113 , showing an increase in concentration between 2012 and 2015, with a subsequent decline. With respect to countries, the average difference between the $\mathrm{HHI}_{c}$ and $\mathrm{LL}_{c}$ was 0.1670 , indicating less concentration in this period. It was observed that large groupings tend to hide the drop in concentration between countries.

Revista Árvore 2021;45:e4540 
The average $\mathrm{HHI}_{\text {con }}(0.7186)$ and the average $\mathrm{HHI}_{\mathrm{s}}$ (0.3309) showed high concentration. For the countries, the average HHI' ${ }_{c}(0.1689)$ showed moderate concentration, in which the $\mathrm{HHI}$ ' went from 0.1210 (2012) to 0.1625 (2018), reaching the maximum HHI' ${ }_{\mathrm{c}}(0.2116)$ in 2015; imports were not concentrated for 2012 and 2013.

The E and E' pointed to a strong concentration for all regional cuts in pellet imports, corroborating the HHI analyses. There was no change in the participants for continents, assuming an upper limit for continents $\left(\mathrm{UL}_{\mathrm{con}}\right)$ equal to 1.6094. Theil's entropy index $\left(\mathrm{E}_{\text {con }}\right)$ started from 0.1888 (2012) and reached 0.5731 (2018), decreasing the concentration level. The average difference among the subcontinents between the upper limit of the subcontinents $\left(\mathrm{UL}_{\mathrm{s}}\right)$ and the Theil entropy index $\left(\mathrm{E}_{\mathrm{s}}\right)$ was 1.5667 , with 2015 being the year with the highest concentration and highest participation. At the country level, the Ec went from 2.3572 (2012) to 2.2322 (2018), and an average $\mathrm{E}_{\mathrm{c}}$ of 2.2357 and an average $\mathrm{UL}_{\mathrm{c}}$ of 4.4624 , providing a strong concentration. The three groups studied had similar behavior from 2015 for the UL and E, decreasing the concentration of imports (2015 to 2018), which once again suggests technological and market expansion. The E' also indicated a decrease in concentration as of 2015 for all levels, meaning that the average $\mathrm{E}_{\text {' }}$, was 0.2601 , which indicated greater concentration given the dominance of the European continent over pellet imports in the world. The $\mathrm{E}_{\text {' }}$, grew from 2014 given the increase in imports in Asia and consequently the concentration decreases. The concentration for the subcontinents $\left(\mathrm{E}_{\mathrm{s}}{ }_{\mathrm{s}}\right)$ and countries $\left(E_{c}^{\prime}\right)$ showed little variation, and the average of the $\mathrm{E}_{\mathrm{s}}$ was 0.4453 , while the $\mathrm{E}_{\mathrm{c}}$, was 0.5013 . Strong concentration was noted for all levels.

The $\mathrm{G}$ at continental $\left(\mathrm{G}_{\text {con }}\right)$, subcontinental $\left(\mathrm{G}_{\mathrm{s}}\right)$ and country $\left(G_{c}\right)$ levels showed increased inequality in pellet imports, mainly for subcontinents and countries. The $\mathrm{G}_{\text {con }}$ ranged between 0.5893 (2012) and 0.5539 (2018), with an average of 0.5706 classifying a medium to strong inequality; the average $\mathrm{G}_{\mathrm{s}}(0.8280)$ was strong to very strong; and the $G_{c}$ very strong to absolute, corresponding to an average of 0.9393 . The increase in importing countries in the period from 2012 to 2015 did not guarantee a reduction in inequality, as new participants did not have a significant participation in pellet imports. Costa et al. (2018) observed a drop in inequality in Brazilian exports of chemical cellulose, even with the increase in importing countries, due to a better distribution between them.

Noce et al. (2005) evaluated the international sawn wood market in the period from 1997 to 1999 , and classified it with very strong to absolute inequality. Noce et al. (2007) inferred strong to absolute inequality in the international wood plywood market from 1998 to 2002 due to the participation of the four main countries above $50 \%$ of exports. Coelho Junior et al. (2013) identified a very strong and absolute inequality in world exports of forest products from 1961 to 2008 .

The HTI for all levels [continents $\left(\mathrm{HTI}_{\text {con }}\right)$, subcontinents $\left(\mathrm{HTI}_{\mathrm{s}}\right)$ and countries $\left(\mathrm{HTI}_{\mathrm{c}}\right)$ ] observed a drop in concentration from 2015 to 2018 , corroborating the other studied indices. The average value of perfect equality for the continents was 0.20 , for subcontinents of 0.0594 , and for countries of 0.0115. In turn, the mean values of the index were: $\mathrm{HTI}_{\text {con }}=0.7793, \mathrm{HTI}_{\mathrm{s}}$ $=0.3598$ and $\mathrm{HTI}_{\mathrm{c}}=0.1339$. Countries were observed as having the lowest concentration level based on the difference between the HTI and the value of perfect equality, followed by subcontinents and continents. The decrease in continental concentration from 2014 should be noted, the same observed in the other indicators.

\section{CONCLUSION}

There was an increase in world pellet imports in the period from 2012 to 2018 from 8.76 million $t$ in 2012 , to 22.15 million $\mathrm{t}$ in 2018 , which represented an increase of $16.67 \%$ p.a. The world import of wood pellets was concentrated on the European continent, under the Northern European subcontinent, in Denmark, the United Kingdom and Italy. South Korea and Japan had the highest average annual increase among the top 10 importing countries, placing the Asian region among the players in wood pellet imports.

The continents had the most concentrated concentration measures due to the growth of Asia and the subcontinents themselves inferred a strong concentration for all indicators studied. Furthermore, countries had a strong concentration for $\mathrm{CR}(\mathrm{k})$ and $\mathrm{E}$, moderately high in HHI and very strong inequality in

Revista Árvore 2021;45:e4540 
G. The highest concentration and inequality among countries was in 2015. The increase in the number of participants was not enough to reduce inequality and concentration in the sector.

Comparative advantages regarding government incentives, as well as the development and improvement of production technology by developed countries (high HDI) may have been the cause for the greater concentration in the initial years of study.

All methods pointed to a deconcentration in pellet imports from 2012 to 2018 , and an increase in market competitiveness. This movement indicated that pellet imports are expanding and that there is strong technological diffusion of energy conversion from densified biomass, making the fuel more accessible. In addition, tax and government incentives have expanded the use of this fuel.

\section{AUTHOR CONTRIBUTIONS}

HCCS, ANdS and LMCJ contributed to the conception and the design of the study.

HCCS and EPSJ executed the methodology.

HCCS wrote the first draft of the manuscript.

LMCJ, ANdS, EPSJ, AMMN and MSJ supplemented and improved the manuscript.

All authors contributed to manuscript revision and read and approved the submitted version.

\section{REFERENCES}

Aghion P, Bloom N, Blundell R, Griffith R, Howitt P. Competition and Innovation : An Inverted-U Relationship. The Quarterly Journal of Economics. 2005;120(2):701-728.

Arranz JI, Miranda MT, Monteiro I, Sepúlveda FJ, Rojas CV. Characterization and combustion beraviour of commercial experimental Wood pellets in south west Europe. Fuel. 2015;142(1):199-207.

Bain J. Industrial organization. New York: Wiley, 1959.

Bowd R, Quinn NW, Kotze DC, Guilfoyle MJ. A systems approach to risk and resilience analysis in the woody-biomass sector: A case study of the failure of the South African wood pellet industry. Biomass and Bioenergy. 2018;108:126-137.

Braga CH, Mascolo JL. Mensuração da concentração industrial no Brasil. Pesquisa e Planejamento Econômico. 1982;12(2):399-454.

Caraschi JC, Garcia DP. A expansão do mercado de pellets de madeira. REMADE. 2012;131.

Coelho Junior LM, Burgos MC, Santos Junior EP, Pinto PALA. Regional concentration of the gross value of production of firewood in Paraíba. FLORAM. 2019c;26:e20170887.

Coelho Junior LM, Medeiros MG, Santos Junior EP, Borges LAC, Joaquim MS, Silva ML. Regional concentration of charcoal production in the state of Paraíba, Brazil (1994 - 2016). Revista Árvore (online). 2019b;43:e430105.

Coelho Junior LM, Rezende JLP, Avila ES, Oliveira AD, Borges LAC. Analysis of the brazilian cellulose industry concentration (1998-2007). CERNE. 2010;16:209-216.

Coelho Junior LM, Rezende JLP, Oliveira AD. Concentração das exportações mundiais de produtos florestais. Ciência Florestal. 2013;23:693-703.

Coelho Junior LM, Santos Júnior EP, Nunes AMM, Simioni, FJ, Abrahão R, Rotela Junior R. Concentration and Spatial Clustering of Forest-Based Thermoelectric Plants in Brazil. IEEE Access. 2020;8:221932-41. doi: 10.1109/ ACCESS.2020.3042945

Coelho Junior LM, Santos Junior EP, Nunes AMM, Souza NA, Borges LAC, Simioni FJ. Concentration and clusters of black liquor thermoelectric plants in Brazil. IEEE Latin America Transactions. 2021;19:2122-2129.

Coelho Junior LM, Selvatti TS, Alencar FV, Santos Junior EP, Borges LAC, Rezende JLP. Global concentration of pulp exports. Floresta. 2018;48:443452.

Coelho Junior LM, Selvatti TS, Alencar FV, Silva ML, Rezende JLP. Global concentration of MDF (Medium Density Fiberboard) exports. Revista Chapingo Serie Ciencias Forestales y del Ambiente. 2019a;25:413-424.

\section{Revista Árvore 2021;45:e4540}

\section{sitf}


Costa TR, Mahanzule RZ, Aguiar GP, Silva

JCGL. Dinâmica da concentração das exportações brasileiras de celulose química (1990-2010). Ciência Florestal. 2018;28(4):1666-75.

Cuenca MAG, Dompieri MHG. Dinâmica espacial da canavicultura e análise dos efeitos sobre o valor bruto da produção, na região dos tabuleiros costeiros da Paraíba, Pernambuco e Alagoas. Revista Econômica do Nordeste. 2016;47(4):91-106.

European Biomass Association - AEBIOM. Statistical Report - European Bioenergy Outlook 2021: 2021. [cited 2021 october 01] Available from: https://bioenergyeurope.org/statistical-report.html

Food and Agriculture Organization of the United Nations - FAO. FAO Data. 2020 [cited 2020 Jan 10]. Available from: http://www.fao.org/faostat/ en/\#data/FO

Gini C. Variabilità e mutuabilità. Contributo allo studio delle distribuzioni e delle relazioni statistiche. Bologna: C. Cuppini; 1912.

Johannsdottir L, Mcinerney C. Calls for Carbon Markets at COP21: a conference report. Journal of Cleaner Production. 2016;124:405-407.

Kon A. Economia industrial. São Paulo: Nobel; 1999.

Kovalyshyn S, Kaygusuz O, Guney MS. Global energy demand and woody biomass. Journal of Engineering Research and Applied Science. 2019;8(1):1119-26.

Le H, Vo T. Concentration and performance in Vietnamese commercial banks. Accounting. 2020;6(2):161-168.

Ministério da Agricultura, Pecuária e Abastecimentos - Mapa. Japoneses querem aumentar exportação de biomassa produzida aqui para o Japão. 2016 [ cited 2020 May 03]. Available from: https:/www.gov.br/ agricultura/pt-br/assuntos/noticias/japoneses-queremaumentar-exportacao-de-biomassa-produzida-aquipara-o-japao.

Ministério das Relações Exteriores - MRE. Como Exportar: França. Brasília: Ministério das Relações Exteriores; 2014. ISBN 85-98712-47-7.

Noce R, Carvalho AMMR, Canto LJ, Silva
LM, Mendes ML. Medida da desigualdade do mercado internacional de compensado. Cerne. 2007;13(1):107-110.

Noce R, da Silva ML, Carvalho RMMA, Soares TS. Concentração das exportações no mercado internacional de madeira serrada. Revista Árvore. 2005;29(3):431-437.

Nunes LJR, Matias JCO, Catalão JPS. Wood pellets as a sustainable energy alternative in Portugal. Renewable Energy. 2016;85:1011-16.

Pinel J. La filière pellets en France: une filière à structurer dans un contexte d'internationalisation rapide du marché. Paris: E-CUBE strategy consultants; 2013.

Proskurina S, Junginger M, Heinimo J, Tekinel B, Vakkilainen E. Global biomass trade for energyPart 2: Production and trade streams of wood pellets, liquid biofuels, charcoal, industrial roundwood and emerging energy biomass. Biofuels, bioproducts and biorefining. 2019;13(2):371-387.

Resende M, Boff H. Concentração industrial. In: Kupfer D, Hasenclever L, Orgs. Economia industrial: fundamentos teóricos e práticas no Brasil. Rio de Janeiro: Campus; 2002.

Resende M. Medidas de concentração industrial: uma resenha. Revista Análise Econômica. 1994;12(21):24-33.

Scherer FM, Ross D. Industrial Market Structure and Economic Performance. Boston: Houghton Mifflin; 1990.

Selvatti TS, Borges LAC, Soares HCC, Souza ÁND, Coelho Junior LM. Global production concentration of medium density fiberboard (MDF) (1995-2016). Rev. Árvore. 2018;42(5):e420506.

Simioni FJ, Moreira JMMP, Fachinello AL, Buschinelli CCDA, da Matsuura, MISF. Evolução e concentração da produção de lenha e carvão vegetal da silvicultura no Brasil. Ciência Florestal. 2017;27(2):731-742. doi: 10.5902/1980509827758

Tavares MAME, Tavares SRL. Perspectivas para a participação do Brasil no mercado Internacional de pellets. Holos. 2015;5(31):292-306.

Trømborg E, Ranta T, Schweinle J, Solberg B,

Revista Árvore 2021;45:e4540 
Skjevrak G, Tiffany DG Economic sustainability for wood pellets production: a comparative study between Finland, Germany, Norway, Sweden and the US. Biomass \& Bioenergy. 2013;57:68-77.
United Nations - UN. The future we want: resolution adopted by the General Assembly. ONU. 2012 [cited 2020 May 20]. Available from: http://www.onu.org. br/rio20/documentos/ 